\title{
Population structure and reproductive biology of Metamysidopsis neritica (Crustacea: Mysidacea) in a sand beach in south Brazil ${ }^{1}$
}

\author{
Patrícia Calil ${ }^{2} \&$ Carlos A. Borzone ${ }^{3}$ \\ ${ }^{1}$ Contribuição número 1762 do Departamento de Zoologia, Universidade Federal do Paraná. \\ 2 Programa de Pós-graduação em Zoologia, Departamento de Zoologia, Universidade Federal do Paraná. \\ Caixa Postal 19020, 81531-980 Curitiba, Paraná, Brasil. E-mail: patecalil@gmail.com \\ ${ }^{3}$ Centro de Estudos do Mar, Universidade Federal do Paraná. Caixa Postal 50002, 3255-000 Pontal do Paraná, Paraná, Brasil.
}

\begin{abstract}
Mysidacea are common sublittoral crustaceans that inhabit all coasts in the world. In this study, the population characteristics and the reproductive biology of Metamysidopsis neritica Bond-Buckup \& Tavares, 1992 were studied in the surf zone of a south Brazilian beach (Atami). Mysids were sampled at monthly intervals from August, 1999 to July, 2000 (total of 29,490 individuals). Individuals were classified into six population categories. The highest abundance occurred in May $(8,665)$ and August $(6,415)$, and lowest in September $(336)$ and December (368). Three main generations were identified, namely the summer, fall and winter generations. The winter generation was the longest (four to five months). The fall generation lasted four months, and the summer one extended from three to four months. Ovigerous females occurred throughout the year, with a greater proportion in July. The number of eggs or larvae varied from one to 16 . Weak associations were found between female length and egg number, egg volume, and the number of larvae with and without eyes. Egg volume increased during the coldest season, whereas the smallest values were recorded during summer. These results suggest a possible direct relationship between egg volume and generation longevity.
\end{abstract}

KEY WORDS. Opossum shrimps; reproductive biology; surf zone; sandy beach.

RESUMO. Estrutura populacional e biologia reprodutiva de Metamysidopsis neritica (Crustacea: Mysidacea) em uma praia arenosa do sul do Brasil. Misidáceos são crustáceos comuns no sublitoral de todo o mundo. Neste estudo as características populacionais e a biologia reprodutiva de Metamysidopsis neritica Bond-Buckup \& Tavares, 1992 foram estudadas na zona de arrebetação de uma praia no sul brasileiro (Atami). Os misidáceoa foram coletados mensalmente no período de agosto/1999 a julho/2000 (total de 29490 exemplares). Os indivíduos foram classificados em seis categorias populacionais. A maior abundância ocorreu em maio (8665) e em agosto (6415), e a menor, em setembro (336) e dezembro (368). Foram identificadas três principais gerações, nomeadas de geração do verão, do outono e do inverno. A com maior longevidade foi a do inverno (quatro a cinco meses). A duração da geração do outono foi de quatro meses e a do verão variou de três a quatro meses. Fêmeas ovígeras foram amostradas durante todo o ano, sendo a maior proporção obtida em julho. $\mathrm{O}$ número de ovos e de larvas variou de um a 16. Foi observada uma fraca relação entre o comprimento das fêmeas e: o número de ovos, o volume dos ovos e o número de larvas com e sem olhos. O volume dos ovos aumentou na estação mais fria, sendo os menores valores registrados no verão. Os resultados sugerem uma possível relação direta entre o volume dos ovos e a logevidade das gerações.

PALAVRAS-CHAVE. Misidáceos; biologia reprodutiva; zona de arrebentação; praia arenosa.

Mysidacea are small, cosmopolitan crustaceans that inhabit the sublittoral of most coastal ecosystems. They play an important ecological role because they are consumed by juvenile forms of numerous species of fish, such as Scomber japonicus Houttyn, 1782 and Menticirrhus littoralis Holbrook, 1860 (MAUCHLINE 1980, Modde \& Ross 1983, Lasiak \& McLachlan 1987). In addition, they are also important in sandy beaches as a food source for the interstitial fauna, macrofauna (WooldRIDGe 1983), and even for some birds (Mauchline 1980, TaKahashi \& KaWAGUCHI 1995). They are very abundant in Brazilian waters, and their taxonomy is reasonable known (COIFMANn 1937, Costa 1964, BACESCU 1968a, b, c, Silva 1970, 1971, Almeida Prado 1974, Bond-Buckup \& Tavares 1991, Murano 1999). However, their biology and ecology have been poorly studied despite of their great abundance in sandy beaches (Loureiro-Fernandes \& GAMA 1996, Rörig et al. 1997, GAMA \& Zamboni 1999, Gama et al. 2002, Borzone et al. 2007). 
Metamysidopsis neritica Bond-Buckup \& Tavares, 1992 is a sand-burrower species found from Texas, USA, to south Brazil. This species is an abundant mysid that inhabits the surf zone of the Atami's sandy beach, Paraná, Brazil. It usually has conspicuous eyes and a characteristic pigmentation in the lateral region of the abdominal segments. Also, the endopod of the uropod bears thirteen to twenty-nine thorns that are not homogeneously distributed all over the margin, being absent from the apices (Bond-Buckup \& Tavares 1992).

Some studies on other species of Metamysidopsis have been done in Brazil. Loureiro-Fernandes \& Gama (1996) studied the moulting cycle of Metamysidopsis munda Zimmer, 1918 in laboratory. GAMA et al. (2002) studied the pos-marsupial life cycle and growth of Metamysidopsis elongata atlantica Bacescu, 1968 under laboratory condition. The present research is a first attempt to describe the reproductive biology and some features of the population dynamics of Metamysidopsis neritica.

\section{MATERIAL AND METHODS}

The coast of the state of Paraná, in southern Brazil $\left(25^{\circ} 20\right.$ $\left.26^{\prime} \mathrm{S}, 48^{\circ} 05-36^{\prime} \mathrm{W}\right)$, stretches for $100 \mathrm{~km}$ in a NE-SW direction. In the northern region, the Ilha do Mel separates the access of the estuarine system of the Baía de Paranaguá from the open sea. South to this access, a $30 \mathrm{~km}$ long coastal plain comprises a single beach with highly variable sandy sediment and morphological characteristics throughout its extension. The Atami beach is located in the northern region of this coastal plain, which opens to the ocean with an intertidal gentle slope and fine to very fine sand sediment (Fig. 1). It is a wide surf zone with 50 to $200 \mathrm{~m}$ and a modal intermediate to dissipative morphodynamic stage (Borzone \& Souza 1997, SoAres et al. 1997).

Monthly diurnal samples were obtained from August, 1999 to July, 2000 during low tide. Four stations were distributed across shore at different depths $(0.2,1.0,1.5$, and $2-4 \mathrm{~m})$ to sample the entire surf zone. An epibenthic dredge with a rectangular mouth of $30 \times 80 \mathrm{~cm}$ was used as sampling device (BRANDT \& BARTHEL 1995). A $0.3 \mathrm{~mm}$ mesh size plankton net was attached to the top and lateral margins of the rectangular mouth. The bottom margin of the plankton net was sewed to a one-inch tickler chain and another tickler chain was added to the mouth $10 \mathrm{~cm}$ in front of the latter. This chain had the purpose of disturbing the bottom in front of the net mouth. This device surveys indiscriminately benthic species that are superficially burrowed in the sand and hypo-pelagic species which are up to $30 \mathrm{~cm}$ above the sea floor. During daytime, more than $90 \%$ of the pelagic mysids occur within this layer above the sandy bottom (ClutTer 1967). Therefore, it can be assumed that all the members of the population within the area were equality sampled. In each sample station, the epibenthic dredge was dragged manually over the bottom along $20 \mathrm{~m}\left( \pm 4.8 \mathrm{~m}^{3}\right)$ during 30 minutes. One haul parallel to the shore was done at each of the first three stations and one haul perpendicular to shore at the fourth, for 30 minutes. Studies

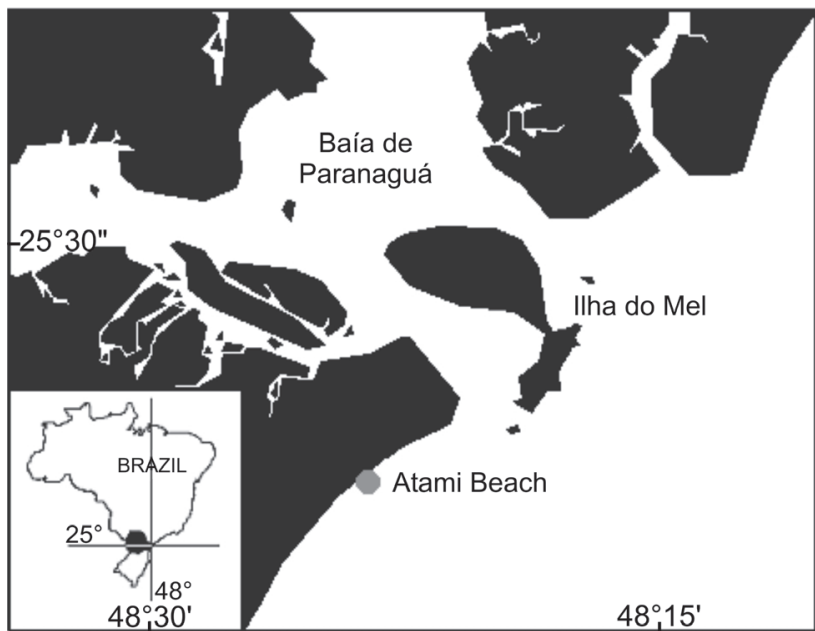

Figure 1. Map of the coast of Paraná, with the location of Atami beach.

about mysid zonation in the surf zone show the importance of parallels hauls at different depths to sample all the population categories of species (TAKAHASHI \& KaWAGUCHI 1995).

Water temperature and salinity at the surf zone were measured, and height $(\mathrm{Hb})$ and period $(\mathrm{T})$ of dominant waves were recorded. Also, sediment samples were obtained at the three first stations for standard mechanical-sieving grain analysis. Mean and standard deviation were computed according to FolK \& WARD (1957) and results expressed as $\phi$ values $\left(\phi=-\log _{2}\right.$ diameter in $\mathrm{mm}$ ) Mean monthly morphodynamic states were computed employing the dimensionless fall velocity parameter $\Omega=\mathrm{Hb} \div \mathrm{Ws} \times \mathrm{T}$ (DeAN 1973), where $H b$ is the breaker height, $W s$ is the mean fall velocity of the beach face sediment and $T$ is the wave period (Wright \& SHORT 1984). A mean value of $\phi 2.9$ obtained from Atami Beach face during 1992/1993 (SOAREs et al. 1997) was used for omega calculations.

Biological samples were fixed and preserved in $7 \%$ formaline. Individuals of $M$. neritica were counted under stereomicroscope and classified into one of the six population categories on the basis of sexual characteristics: (1) juveniles (secondary sexual characteristics are absent); (2) immature males (developing secondary sexual characteristics); (3) mature males (secondary sexual characteristics completely developed); (4) immature females (rudimentary empty marsupium present); (5) empty females (secondary sexual characteristics fully developed, larger than immature, but without eggs or larvae in the marsupium); (6) ovigerous females (mature females with eggs or larvae in the marsupium) (Mauchline 1980, Delgado et al. 1997). The ovigerous females were classified into three stages of embryonic and post-embryonic development based on the morphological criteria of the embryos: stage 1 (rounded egg containing embryo), stage 2 (lengthened larva with antennae and thoracic appendages developed, but without eyes) and stage 3 
(lengthened larva with pigmented and stalked eyes) (MAUCHLINE 1980).

The carapace length (Lc) was measured from the base of the stalked eyes to the posterior lateral margin of the carapace of about 200 individuals of each population category (chosen randomly among sampling stations and over the year). The carapace length is usually used to represent individual size (mainly in Peracarida) because it is considered to be more accurate than the total length, which is affected by the anima contraction after the preservation in formaline or ethanol (Amaratunga \& Corey 1975, Delgado et al. 1997). Nevertheless, transformation to total length was made using the relationship between the carapace length and total length (obtained from the base of the stalked-eyes to the posterior end of the telson, excluding the setae) calculated for the following categories: juveniles, males (immature + mature), and females (immature + empty + ovigerous). All measures were made under a stereoscopic microscope. This transformation allows an easier comparison of our results with those of other species.

Monthly histograms with total length of each population category were used to analyze the population structure of M. neritica using $0.2 \mathrm{~mm}$ size-class intervals. All four sample stations were combined. The percentage of different categories was determined in relation to the total individuals collected each month. To identify the existence of significant differences between the proportions of each sex, we employed a $\chi^{2}$ test ( $\mu=0.05$ ), using the sex ratio (females/males) of the complete dataset.

The eggs and larvae inside the marsupium of brooding females during the year were counted. A total of 297 ovigerous females in stage 1, 355 in stage 2, and 202 in stage 3 were randomly chosen from all months of the year (about 30 individuals per month). The relationship between the size (Lt) of the ovigerous females and the number of embryos or larvae were investigated using simple linear regression. Two diameters (larger and smaller) were measured to estimate the egg volume based on the ellipsoid-egg formula: $\mathrm{V}=1 / 6 \times \pi \times \mathrm{I} 3$ (V: volume; I: mean diameter) (Jones \& Simons 1983). Mean egg volumes in each sampled month were compared using ANOVA and a HSD Tukey test for unequal sample sizes as a post-hoc test.

\section{RESULTS}

Surf zone water temperature ranged from $17.3^{\circ} \mathrm{C}$ in winter to $28^{\circ} \mathrm{C}$ in summer, showing strong seasonal variation. Salinity ranged from 31.8 to 37.1 , without a clear seasonal pattern. Values of wave height and period determined "omega" values ranged from 4.4 (intermediate stage) to 25.3 (dissipative stage), with most values showing a recurrent dissipative stage ( $\Omega>5$, SHORT 1996). However, summer months showed the lowest values of the morphodynamic parameter (Tab. I).

The sediments were composed by quartz sands (> 99\%) with few fine materials. Mean grain size at the surf zone varied from $\phi 3$ (very fine sand) to $\phi 2$ (fine sand), with little across-
Table I. Mean values of temperature (Temp) and salinity (Sal) of water, wave height $(\mathrm{Hb} \mathrm{cm})$ and period $(T \mathrm{sec})$ and morphodynamic stages ( $\Omega$ : Deans parameter) at Atami beach surf zone from August 1999 to July 2000.

\begin{tabular}{lccccr}
\hline \multicolumn{1}{c}{ Date } & Temp $\left({ }^{\circ} \mathrm{C}\right)$ & Sal & $\mathrm{Hb}(\mathrm{cm})$ & $\mathrm{T}(\mathrm{sec})$ & \multicolumn{1}{c}{$\Omega$} \\
\hline Aug/1999 & 19.5 & 31.8 & 100 & 14 & 9.7 \\
Sep & 20.3 & 34.6 & 150 & 11 & 18.6 \\
Oct & 21.3 & 33.8 & 80 & 14 & 8.0 \\
Nov & 23.6 & 35.4 & 60 & 14 & 6.0 \\
Dec & 24.6 & 35.5 & 50 & 18 & 3.9 \\
Jan/2000 & 28.0 & 32.8 & 70 & 8 & 14.6 \\
Feb & 26.0 & 36.3 & 60 & 14 & 7.1 \\
Mar & 26.9 & 32.7 & 50 & 14 & 5.9 \\
Apr & 24.9 & 36.6 & 90 & 13 & 9.7 \\
May & 21.9 & 36.8 & 180 & 10 & 25.3 \\
Jun & 21.3 & 37.1 & 120 & 14 & 12.1 \\
Jul & 17.3 & 37.1 & 40 & 12 & 4.4 \\
\hline
\end{tabular}

shore variation. Summer and fall months exhibited the lowest values. Sorting varied from $\phi 0.198$ (very well sorted) to $\phi 0.624$ (moderately sorted), with smallest values at the shallow station. Temporal variation showed an increase in sorting values from August to July.

During the sampling period, only three mysid species were collected. $M$. neritica was the most abundant $(29,490$ individuals), followed by Bowmaniella brasiliensis Bacescu, 1968 (1,752 individuals), and Mysidopsis coelhoi Bacescu, 1968 (344 individuals).

All the six population categories of $M$. neritica were abundantly collected: 6,493 juveniles, 6,331 immature males, 6,043 mature males, 6,150 immature females, 1,513 empty females and 2,960 ovigerous females. Months with highest abundance were May (8,665 individuals), August (6,415 individuals), June (3,862 individuals) and March (3,514 individuals). Low abundance appeared in September (336 individuals), December (368 individuals), October (447 individuals), and July (452 individuals) (Tab. II).

Table II. Minimum and maximum values of total length in $\mathrm{mm}(\mathrm{Lt})$ and total number $(n)$ of each population categories collected from August 1999 to July 2000.

\begin{tabular}{lccc}
\hline Population categories & Minimum & Maximum & $\mathrm{n}$ \\
\hline Juveniles & 0.77 & 4.10 & 6,493 \\
Immature males & 1.87 & 4.58 & 6,331 \\
Mature males & 2.76 & 6.05 & 6,043 \\
Immature females & 1.56 & 5.71 & 6,150 \\
Empty females & 2.79 & 6.50 & 1,513 \\
Ovigerous females & 3.11 & 6.50 & 2,960 \\
\hline
\end{tabular}


All the three relationships between carapace length (Lc) and total length (Lt) showed high and significant values of correlation (juveniles: $\mathrm{n}=215, \mathrm{r}^{2}=0.93$, males: $\mathrm{n}=224, \mathrm{r}^{2}=0.94$, females: $\mathrm{n}=238, \mathrm{r}^{2}=0.95$ ).

The mean sex ratio (female/male) calculated for the complete data was 1.10, and ranged from 0.54 (February/00) to 1.65 (July/00) (Fig. 2). This ratio was not significantly different from $1\left(\chi^{2}=1.70, \mathrm{DF}=11, \mathrm{p}>0.05\right)$.

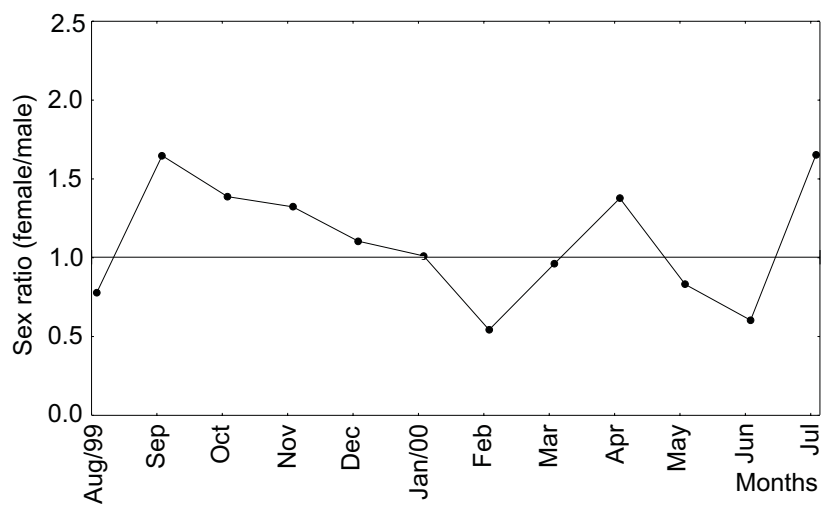

Figure 2. Monthly variation in sex ratio (female/male) of $M$. neritica at Atami beach from August, 1999 to July 2000.

Population categories representing the percentage of the total number of individuals collected each month showed considerable temporal variation. Juveniles were dominant in August (47.60\%) and fewer appeared in March and July (1.99\%). Minimum Lt value of $0.77 \mathrm{~mm}$ was obtained in August, and maximum of $4.10 \mathrm{~mm}$ in December (Fig. 3). Immature males reached maximum percentage in June (38.19\%) and February (33.71\%) and minimum in July (4.42\%). The smallest Lt value was found in summer (December and February: Lt $=1.87 \mathrm{~mm}$ ) and the highest in May (Lt $=4.58 \mathrm{~mm}$ ) (Fig. 3). A large percentage of mature males was detected in March and July (40.64\% and $32.52 \%$ respectively). The lowest percentage was observed in June (12.30\%). The smallest Lt occurred in November (Lt = $2.76 \mathrm{~mm}$ ) and the largest in August (6.05 mm) (Fig. 3) (Tab. II).

During all sampling period, values of immature females varied from $27.60 \%$ in May to $12.10 \%$ in August. Immature females presented the greatest variation in Lt, from 1.56 to 5.71 mm, both values observed in August (Fig. 3). Empty females were the least represented population category, with a maximum of $16.96 \%$ recorded in April, and minimum of $1.06 \%$ recorded in June. Lt size varied from $2.79 \mathrm{~mm}$ in February to $6.50 \mathrm{~mm}$ in August (Fig. 3). Ovigerous females reached a maximum value in July (38.94\%) and a minimum in June and May (5.15 and $7.56 \%$ respectively). The smallest individual was recorded in March $(\mathrm{Lt}=3.11 \mathrm{~mm})$ and the largest in August $(\mathrm{Lt}=$ $6.50 \mathrm{~mm}$ ) (Fig. 3, Tab. II).

Despite the presence of all categories during the whole period and the overlap of the different generations, progression of the main modes suggests the existence of three main generations. The first one, named winter generation, started in August with a large cohort. These juveniles became the immature females and males observed in September and October, which developed to mature males and ovigerous females in October and November. These ovigerous females originated a new generation in December and January. The winter generation longevity was of about four to five months (Fig. 3). The generation of December and January, named the summer generation, became immature females and males in February, and mature individuals in March that developed a third generation in April, named the fall generation. The longevity of the summer generation was about three to four months, less than the winter generation (Fig. 3). The fall generation became the immature individuals of May and June, and the mature one of July, developing the winter generation and closing the annual biological cycle of $M$. neritica. The overfall generation had an intermediate longevity of about four months.

Mature females (empty + ovigerous) were recorded in all samples. The greatest percentage of mature females (in relation to the total number of individuals) was detected in July (44.69\%), April (31.34\%), and during spring months (September, October, and November). The lowest percentage was observed in June (6.21\%) and August (10.85\%). Within ovigerous females, a great percentage of stage 2 was observed in July $(54.95 \%)$. Stage 3 reached a maximum percentage in February (18.87\%) (Tab. III).

Mean length of stage 1 females $( \pm \mathrm{SD})$ was $4.67 \pm 0.53$ $\mathrm{mm}$. The largest individual was $6.0 \mathrm{~mm}(\mathrm{Lt})$ with 12 eggs. The smallest had an Lt of $3.26 \mathrm{~mm}$ with 9 eggs. Mean egg number $( \pm \mathrm{SD})$ was $8.52 \pm 2.42 \mathrm{~mm}$. The highest number of eggs was 14 , from females of 4.37 to $5.50 \mathrm{~mm}(\mathrm{Lt})$. The lowest was 2 , from a female of $4.89 \mathrm{~mm}$ (Lt). Number of eggs carried by the females was significantly related to size $(\mathrm{Lt})(\mathrm{p}<0.05)$, but with a small correlation value (Fig. 4).

Annual mean length of stage 2 females $( \pm \mathrm{SD})$ was $4.71 \pm$ $0.50 \mathrm{~mm}$, ranging from $3.40 \mathrm{~mm}$ (with 10 larvae without eyes) to $6.50 \mathrm{~mm}$ (carrying 11 larvae without eyes). Mean value of eyeless larvae $( \pm \mathrm{SD})$ was $8.20 \pm 2.37 \mathrm{~mm}$, the highest number was 16 from a female of $5.88 \mathrm{~mm}(\mathrm{Lt})$, and the lowest was 3 from females of 3.61 to $5.01 \mathrm{~mm}(\mathrm{Lt})$. The relation between size (Lt) and number of eyeless larvae was also significant $(\mathrm{p}<0.05)$, but with a small correlation again (Fig. 5).

Annual mean length of stage 3 females was $4.77 \mathrm{~mm} \pm$ 0.54 (mean $\pm \mathrm{SD}$ ), ranging from $3.42 \mathrm{~mm}$ (with five stalkedeye larvae) to $6.05 \mathrm{~mm}$ (carrying two stalked-eye larvae). The mean value of eyeless larvae was $7.50 \mathrm{~mm} \pm 2.78 \mathrm{~mm}$ (mean \pm $\mathrm{SD})$. The highest number of larvae was 14 from females of 5.64 and $5.66 \mathrm{~mm}(\mathrm{Lt})$, and the lowest was three from females of 3.61 to $5.01 \mathrm{~mm}(\mathrm{Lt})$. We found only one $4.29 \mathrm{~mm}(\mathrm{Lt})$ female (with no damaged marsupium) carrying only 1 stalked-eye larvae. The relation between size (Lt) and number of stalked-eye 

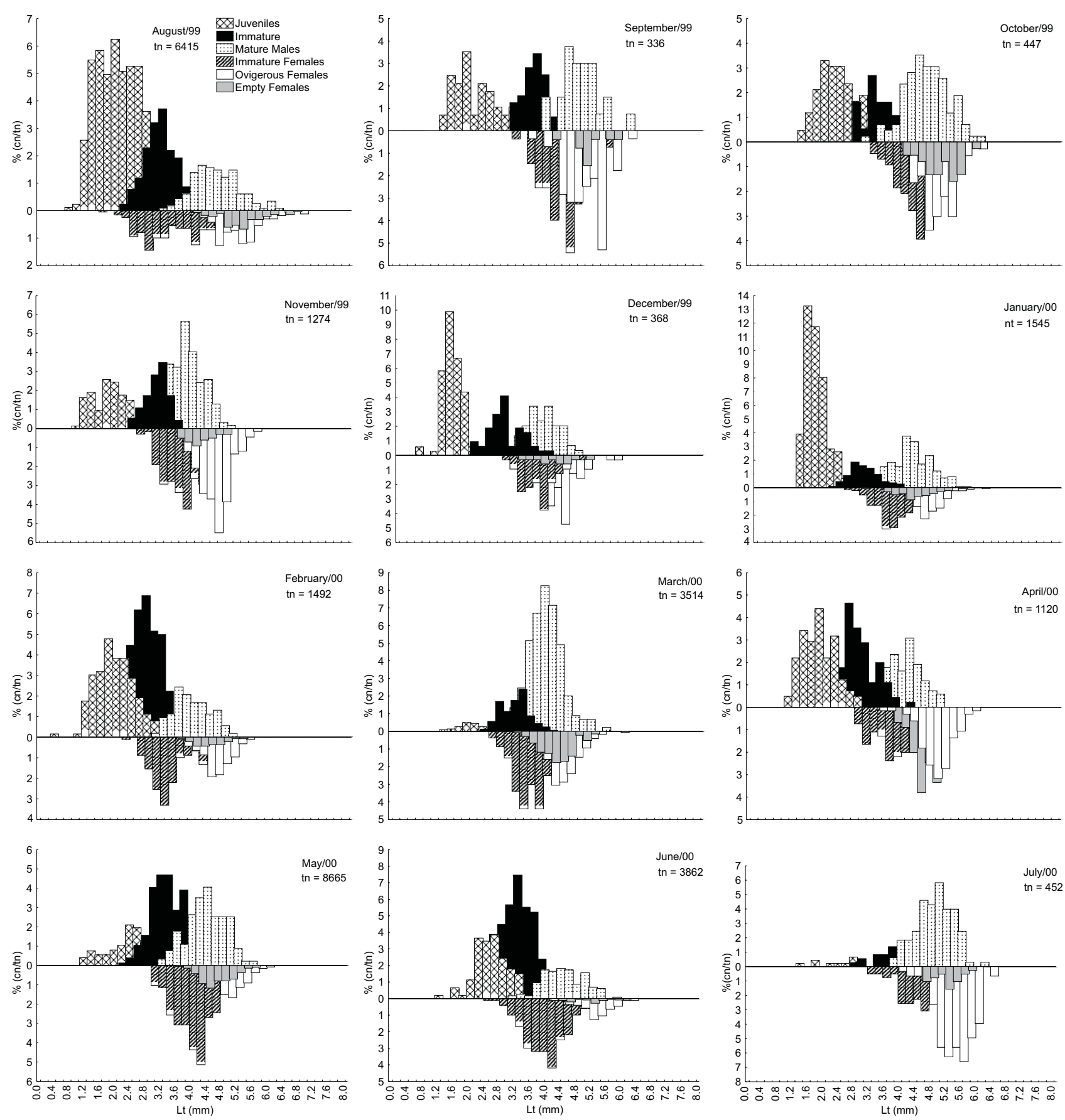

Figure 3. Monthly distribution in total length frequencies (\%) of M. neritica at Atami beach from August, 1999 to July, 2000. (Lt) Total length ( $\mathrm{mm}),(\mathrm{cn})$ number of each population category recorded for each month, (tn) total number of individuals collected in each month.

larvae was significant $(\mathrm{p}<0.05)$ and with a slightly greater correlation than the other two (Fig. 6).

Mean egg volume of all females was $0.025 \pm 0.006 \mathrm{~mm}^{3}$. We obtained values from $0.013 \mathrm{~mm}^{3}$ (female $\mathrm{Lt}=4.51 \mathrm{~mm}$ ) to
$0.038 \mathrm{~mm}^{3}$ (female $\mathrm{Lt}=5.63 \mathrm{~mm}$ ). Mean egg volume was significantly related to the size $(\mathrm{Lt})$ of the stage 1 females $(\mathrm{p}<0.05)$ with the greatest value of correlation (Fig. 7). Monthly mean egg volume variation indicated a clear increase in volume dur- 

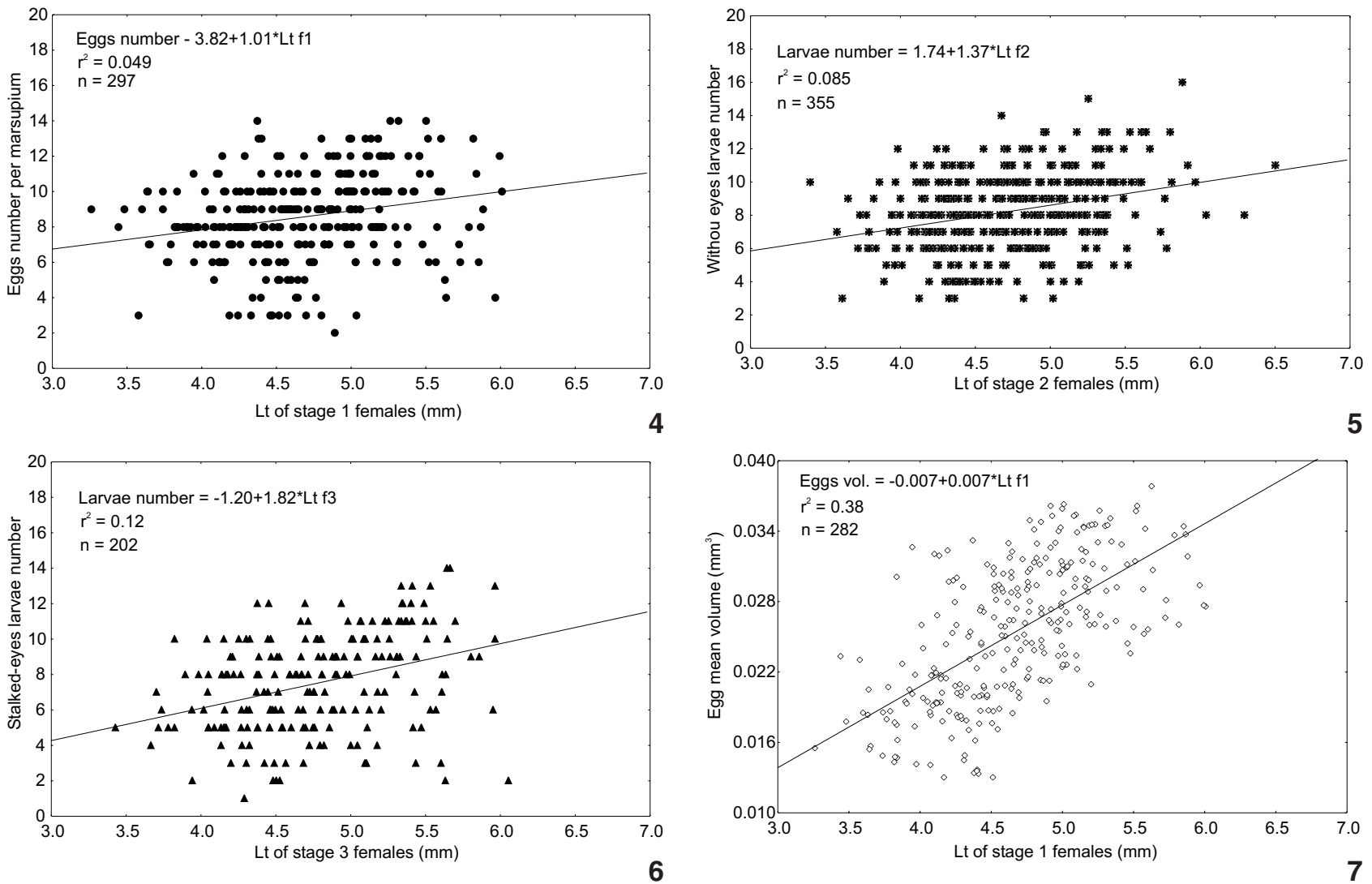

Figures 4-7. Relationship between: (4) egg number and total length (Lt) of stage $1 ;(5)$ number of eyeless larvae and total length (Lt) of stage $2 ;(6)$ number of stalked-eyes larvae and total length (Lt) of stage 3 ; (7) mean egg volume and total length (Lt) of stage 1 females of $M$. neritica at Atami beach.

Table III. Mature females $(\mathrm{mf})$ during the year. $\mathrm{n}$ : total number of individuals sampled per month; mf: total number of mature females; ( $\mathrm{mf} \%$ ) percentage of mature females in relation to the total number of individuals collected per month; (of \%) percentage of ovigerous females in relation to the total number of mature females; (f1, f2 e f3\%) percentage of ovigerous females with eggs (stage 1), without eggs larvae (stage 2 ) and stalked-eyes larvae (stage 3 ), respectively.

\begin{tabular}{crrrrrrr}
\hline Date & $\mathrm{n}$ & $\mathrm{mf}$ & $\mathrm{mf} \%$ & $\mathrm{of} \%$ & $\mathrm{f} 1 \%$ & $\mathrm{f} \%$ & \multicolumn{1}{c}{$\mathrm{F} \%$} \\
\hline Aug/1999 & 6415 & 696 & 10.85 & 67.24 & 30.17 & 30.32 & 6.75 \\
Sep/1999 & 336 & 89 & 26.49 & 85.39 & 31.46 & 44.94 & 8.99 \\
Oct/1999 & 447 & 114 & 25.50 & 66.67 & 22.81 & 42.98 & 0.88 \\
Nov/1999 & 1274 & 342 & 26.84 & 85.67 & 27.48 & 47.08 & 11.11 \\
Dec/1999 & 368 & 77 & 20.92 & 83.12 & 36.36 & 31.17 & 15.58 \\
Jan/2000 & 1545 & 218 & 14.11 & 67.89 & 34.40 & 22.02 & 11.47 \\
Feb/2000 & 1492 & 159 & 10.66 & 79.24 & 15.72 & 44.65 & 18.87 \\
Mar/2000 & 3514 & 842 & 23.96 & 61.52 & 5.82 & 44.06 & 11.64 \\
Apr/2000 & 1120 & 351 & 31.34 & 45.87 & 11.39 & 25.36 & 9.12 \\
May/2000 & 8665 & 1143 & 13.19 & 57.30 & 27.12 & 19.68 & 10.50 \\
Jun/2000 & 3862 & 240 & 06.21 & 82.92 & 32.08 & 41.67 & 9.17 \\
Jul/2000 & 452 & 202 & 44.69 & 87.13 & 21.78 & 54.95 & 10.39 \\
\hline
\end{tabular}

Revista Brasileira de Zoologia 25 (3): 403-412, September, 2008 
ing the coldest seasons (winter and spring), and a decrease during summer (Fig. 8). Mean egg volume of stage 1 females from the three months immediately before a new generation (November, April and July) was considered different from each other when analyzed through ANOVA ( $\mathrm{SS}=0.0029, \mathrm{~F}_{2,74}=138.72$, $\mathrm{p}<0.05$ ) (Tab. IV). According to Tukey post-hoc test, the three monthly are different among each other $(\mathrm{p}<0.05)$.

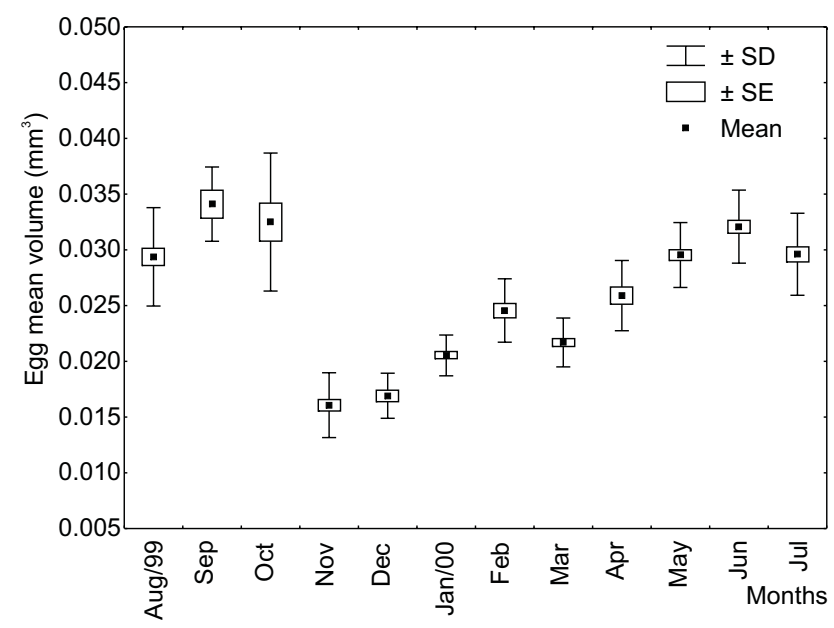

Figure 8. Monthly mean egg volume of $M$. neritica at Atami beach from August, 1999 to July, 2000. (SD) standard deviation, (SE) standard error.

Table IV. ANOVA test among the mean egg volume from stage 1 females found in November/1999, April and July/2000. (n) Females number, (SEM) mean standard error.

\begin{tabular}{llll}
\multicolumn{1}{c}{ Months } & $\mathrm{n}$ & Mean & SEM \\
\hline Nov/1999 & 33 & 0.016 & 0.00051 \\
Apr/2000 & 16 & 0.026 & 0.00079 \\
$\mathrm{Jul} / 2000$ & 28 & 0.030 & 0.00070 \\
\hline
\end{tabular}

\section{DISCUSSION}

Mysids from Atami Beach surf zone are composed by two species, M. neritica and Bowmaniella brasiliensis, with an occasional occurrence of Mysidopsis coelhoi. Metamysidopsis neritica was the most abundant species, occurring in large quantities all year long and in all sampled depths. Bowmaniella brasiliensis also occurred during the studied year, but was less common. The high abundance values recorded during the whole year for M. neritica species suggest that it is a resident species of Atami Beach surf zone, extending its distribution to deeper areas and being an abundant food source for higher trophic levels.

As many other species of mysids, M. neritica presented considerable fluctuations in its abundance. In this work, the highest abundance values occurred in the fall and the lowest in the spring. MaUchline (1980) showed strong seasonal variation in the number of individuals of 23 species of mysids. AlmeIDA Prado (1974) found, in the Cananéia region $\left(25^{\circ} \mathrm{S}, 48^{\circ} \mathrm{W}\right)$, the maximum abundance of $M$. elongata atlantica and Mysidospis tortonesei Bacescu, 1968 in the spring, and the minimum abundance in the summer. Wooldridge (1981) found, in South Africa $\left(33^{\circ} \mathrm{S}, 25^{\circ} \mathrm{W}\right)$ for Gastrosaccus psammodytes Tattersall, 1958, the highest peak of abundance in the summer (December, 1978), followed by the lowest, in the fall (April, 1978). Temperature and salinity do not seem to be the main regulating factor of mysid distribution, which seems more susceptible to other factors, such as food availability, substrate type, predation, and water depth (Рezzack \& Corey 1979, Webb \& Wooldridge 1987, McKenney 1994, BALDó et al. 2001). In Atami Beach, water temperature and salinity did not vary greatly and thus probably do not regulate presence and abundance of $M$. neritica, which was collected in large quantities at different depths all year long.

There are no data concerning tolerance to temperature and salinity of M. neritica. However, some laboratory studies have analyzed such relations for the species M. elongata atlantica, which is widely distributed in the littoral of the state of Rio Grande do Sul, Brazil. GAMA \& ZAMBONI (1999) showed that the most adequate temperature for the maintenance of this species in laboratory was about $20 \pm 1^{\circ} \mathrm{C}$. Individuals aged from 1 to 5 days in the species that had high tolerance to lower salinity (15 and 18), whereas adults, mostly females, showed more sensitivity to lower salinity. On the other hand, Greenwood et al. (1989) reported a high tolerance to salinity variation (from 3.5 to 35.0 ) in adults of Mesopodopsis slabberi Van Beneden, 1861.

In fact, Evariations in abundance may not be related to seasonal variations in hydrodynamics parameters but also result from the difficulty of sampling mobile organisms with aggregated behaviour (Mauchline 1980, Allen 1984). Samples with a higher number of replicates should be necessary to effectively determine patterns of variation in abundance during the year.

Different aspects of the biology of mysids, such as growth and longevity, depend on latitude. For instance, in species living in shallow water, there is an extension of the reproductive phase with a decreasing in latitude (Delgado et al. 1997). MAUChline (1980) showed that mysids of latitudes between $40^{\circ} \mathrm{S}$ and $\mathrm{N}$ normally reproduce in a continuous fashion. Species that inhabit shallow water in temperate regions show many generations during the year and one female could produce successive offspring (Delgado et al. 1997). An increase in the reproductive potential of a population is related to an accelerated ontogenetic development that results in a fast maturation of the individuals, allowing the production of many generations per year. In subtropical latitudes (São Paulo coast, $25^{\circ} \mathrm{S}$ ) M. elongata atlantica and Brasilomysis castroi Bacescu, 1968 showed spawning females during all seasons of the year, although the existence of successive generation was not clearly identified (Almeida Prado 1974). 
In the present work, M. neritica showed the existence of continuous reproduction, with the presence of spawning females during the whole year. For mysids species with a wide latitudinal distribution, life cycles are more complex at lower latitudes due to their almost continuous breeding throughout the year. This continuous breeding results in the overlap of the different generations that can hardly be distinguished in field data. However, analysis of length frequency distribution allows the identification of main periods of recruitment in summer (December/January generation), in autumn (April generation) and in winter (August generation). Species with continuous reproduction and various generations per year usually inhabit shallow marine waters in latitudes between 25 and $50^{\circ}$ with main cohorts in spring, summer and autumn (MAUCHLINE 1965, 1971b, 1980, San Vicent \& Sorbe 1993, Garnacho et al. 2001). Due to winter low temperatures, many mysid species could not breed during this season (MAUCHLINE 1980, Richoux et al. 2004). Metamysidopsis neritica, however, showed a winter generation, which could be related to the moderated decrease of the water temperature during this season at Atami Beach.

The longevity of individuals of $M$. neritica depends on their generation. The highest life expectancy seems to be found in individuals belonging to winter generation, and the lowest to summer generation. Experimentally, Pezzack \& Corey (1979) showed that higher water temperature and food availability in the summer contribute to faster growth, maturation and death of the individuals. In temperate latitudes, the longevity of the generations born during winter could exceed even twice those born during the summer due to the lower food availability that would delay their growth (MAUCHLINE 1985). The winter generation of $M$. neritica showed a less expressive growth reduction and higher longevity than in the case of temperate species.

Mysids can exhibit different sizes according to local environmental conditions and life stage (Mauchline 1980). For example, spawning female size may vary from $1.8 \mathrm{~mm}$ (Amathimysis cherados, Brattegard, 1974) (BRATTEGARD 1974) to 60 mm (Eucopia sculpticauda, Faxon, 1893) (FAGE 1952). Metamysidopsis neritica presented wide size variation, between $0.77 \mathrm{~mm}$ (juvenile) and $6.50 \mathrm{~mm}$ (spawning female). Juveniles reached a maximum of $4.10 \mathrm{~mm}$, a length very close to that recorded in individuals of the same category of $M$. elongata atlantica on the coast of the state of Rio Grande do Sul (GAma et al. 2002). Immature males of $M$. neritica presented maximum length not much higher than those of juveniles $(4.58 \mathrm{~mm})$. Immature females were larger $(5.71 \mathrm{~mm})$ than immature males. Mature males and females of $M$. neritica were larger than those of M. elongata atlantica (GAMA et al. 2002). For M. neritica, the largest spawning female measured $6.50 \mathrm{~mm}$, and was smaller than largest $M$. elongata atlantica spawning female $(7.12 \mathrm{~mm})$.

Variation in sex ratio (females/males) of $M$. neritica during the sampled period was not significantly different from 1. The same was reported for M. elongata atlantica (GAMA \& ZAMBONI 1999). However, the number of females exceeded the number of males in seven of the 12 sampled months, a pattern also reported for other species of mysid (e.g. Neomysis americana, Smith, 1873) (Pezzack \& Corey 1979).

The number of offspring per mysid female seems to be very variable between species and regions (ClutTer \& THeILACKer 1971, Mauchline 1980). In M. neritica, the quantity of eggs or larvae found inside the female marsupium varied from 1 to 16 larvae. Other species presented more pronounced variations, such as Neomysis integer Leach, 1814 in a region near Amsterdam (6 to 72 eggs or larvae in females up to $17 \mathrm{~mm}$ ) (MAUchline 1971b), and M. slabberi in western Mediterranean (near Spain) ( 1 to 22 eggs or larvae for females of different sizes) (Delgado et al. 1997). Seasonal variations of abiotic factors, such as water temperature and salinity, as well as availability of food resources, could influence fecundity variation in a population (Pеzzack \& COREY 1979). Low variation of such factors in Atami Beach may explain the low variation in eggs and larvae found for M. neritica in this study.

The decrease in the mean number of eggs, eyeless larvae and larvae with eyes found in the marsupials of M. neritica (8.52, 8.2 and 4.77 , respectively) suggest that mortality occurred during the embryonic development, as indicated by MAUCHLINE (1980), for others species.

In mysids, as in many other crustacean groups, larger females exhibit higher fecundity, carrying more eggs or larvae in their marsupials (MaUchline 1971a, 1973, 1980, Delgado et al. 1997). Very low correlation coefficients between eggs number, larvae with and without eyes number and size of females were found for M. neritica in this study. Pezzack \& Corey (1979) reported, for other species, a considerable variation of offspring size within the same female, as was observed by $M$. neritica. Furthermore, natural loss of eggs and larvae within the marsupium during incubation period (CLUTTER \& THeIlaCKer 1971) and the loss derived from the laboratorial manipulation cannot be ignored. However, other species reared in laboratory showed low correlation between female size and number of offspring (MAUCHLINE 1973).

The correlation between mean egg volume and female size in stage 1 of $M$. neritica was significant and high. If larger eggs tend to be more viable and have higher chances of surviving until becoming adults (HINEs 1982), this species may invest more in quality than in quantity of eggs. The same relationship was observed by MaUchline (1973) in 10 other species of mysids.

For $M$. neritica, such results must be confirmed by future studies, including laboratory experiments. More details about the biology of $M$. neritica could be determined in experiments in laboratory. Such results are of great importance for a more complete and precise interpretation of the results obtained during field work. A great understanding of the life history of mysids from the Brazilian littoral is highly necessary to implement the knowledge about the ecological role of these organisms in sandy beaches. 


\section{ACKNOWLEDGEMENTS}

We thank the financial and logistic support from CAPES, Centro de Estudos do Mar and Programa de Pós-graduação em Zoologia, Universidade Federal do Paraná. We also thank Luciano Lorenzi and Ismar A. Sauaf for their support in this work.

\section{LITERATURE CITED}

Allen, D.M. 1984. Population dynamics of the mysid shrimp Mysidopsis bigelowi W.M. Tattersall in a temperate estuary. Journal of Crustacean Biology 4 (1): 25-34.

Almeida Prado, M.S. 1974. Sistemática dos Mysidacea (Crustacea) na região de Cananéia. Boletim do Instituto Oceanográfico de São Paulo 23: 47-87.

Amaratunga, T. \& S. Corey. 1975. Life history of Mysis stenolepis Smith (Crustacea, Mysidacea). Canadian Journal of Zoology 53: 942-952.

BACESCU, M. 1968a. Contribution to the knowledge of the Gastrosaccinae psammobionte of the tropical America, with the description of a new genus (Bowmaniella n. g.) and three new species of its frame. Travaux du Muséum d'Histoire naturelle Grigore Antipa 8: 355-373.

BACESCU, M. 1968b. Afromysis guinensis sp. nov. and Brasilomysis castroi n. g. sp. nov. from the waters of Tropical Atlantic. Revue Roumaine de Biologie, Serie de Zoologie 13 (2): 75-86.

BACesCu, M. 1968c. Étude des quelques Leptomysini (Crustacea, Mysidacea) des eaux du Brésil et de Cuba: description d'un genre et de cinq autres taxons nouveaux. Annali del Museo Civico di Storia Naturale Giacomo Doria 77: 231-249

Baldó, F.; L.J. TaRACido; A.M. ArIas \& P. DraKe. 2001. Distribution and life history of the mysid Rhopalophthalmus mediterraneus in the Guadalquivir estuary (SW Spain). Journal of Crustacean Biology 21: 961-972.

Bond-Buckup, G. \& L.M.G. Tavares. 1991. Os Mysidacea da Região Litorânea e Estuarina de Tramandaí, RS, Brasil (Crustacea, Peracarida, Mysidacea). Revista Brasileira de Zoologia 7: 4757.

Bond-Buckup, G. \& L.M.G. Tavares. 1992. Metamysidopsis neritica, a new Peracarid from the coastal waters of South Brazil (Crustacea, Mysidacea). Atlântica 4: 65-71.

Borzone, C.A. \& J.R.B. SouzA. 1997. Estrutura da macrofauna bentônica no supra, meso e infralitoral de uma praia arenosa do Sul do Brasil. Oecologia Brasiliensis 3: 197-212.

Borzone, C.A.; L. Lorenzi \& P. CALIL. 2007. Cross-shore mysidacea distribution in two sandy beaches with contrasting morphodynamics. Revista Brasileira de Zoologia 24 (4): 943-949.

Brandt, A. \& D. Barthel. 1995. An improved supra and epibenthic sledge for catching Peracarida (Crustacea, Malacostraca). Ophelia 43 (1): 15-23.

Brattegard, T. 1974. Additional Mysidacea from shallow water on the Caribbean coast of Colombia. Sarsia 57: 47-86.
Clutter, R.I. 1967. Zonation of nearshore Mysids. Ecology 48 (2): 200-208.

Clutter, R.I. \& G.H. Theilacker. 1971. Ecological efficiency of a pelagic mysid shrimp; estimates from growth, energy budget, and mortality studies. Fishery Bulletin 69 (1): 93-115.

CoIfmann, I. 1937. Misidacei raccolti dalla R. corvetta Vettor Pisani negli anni 1882-85. Annuario del Museo Zoologico della R. Universita di Napoli, Nuova Serie, 7 (3): 1-14.

Costa, H.R. 1964. Notas sobre os Mysidacea da Costa Brasileira. Boletim do Museu Nacional 247: 1-9.

DeAn, R.G. 1973. Heuristic models of sand transport in the surf zone. Proceedings of the Conference on Engineering Dynamics in the Surf Zone. Sydney: 208-214.

Delgado, L.; G. Guerao \& C. Ribera. 1997. Biology of the mysid Mesopodopsis slabberi (van Beneden, 1861) (Crustacea, Mysidacea) in a coastal lagoon of the Ebro Delta (NW Mediterranean). Hydrobiologia 357 (1-3): 27-35.

FAGE, L. 1952. Etude écologique de la variation des caractères differentiels des espèces et des populations. Annales de la Société Zoologique de Belgique 83: 1-20.

FolK, R.L. \& W.C. WARD. 1957. Brazos River Bar: a study in the significance of grain size parameters. Journal of Sedimentary Petrology 27 (1): 3-26.

Gama, A.M.S. \& A.J. Zamboni. 1999. Aspectos da biologia e do cultivo de Metamysidopsis elongata atlantica para uso em testes de toxicidade. Nauplius 7: 127-139.

Gama, A.M.S.; M.A. MonTú \& L.F.M. Gusmão. 2002. Ciclo de vida pós-marsupial e crescimento de Metamysidopsis elongata atlantica (Crustacea, Mysidacea, Mysidae) em cultivo de laboratório. Iheringia, Série Zoologia, 92 (1): 77-83.

Garnacho, E.; P.A. Tyler \& L.S. Peck. 2001. Reproduction, seasonality, and copper toxicity in the coastal mysid Praunus flexuosus. Journal of the Marine Biological. Association of the United Kingdom 81: 433-440.

Greenwood, J.G.; M.B. Jones \& J. Greenwood. 1989. Salinity effects on brood maturation of the mysid crustacean Mesopodopsis slabberi. Journal of the Marine Biological. Association of the United Kingdom 69: 683-694.

Hines, A.H. 1982. Allometric constraints and variables of reproductive effort in brachyuran crabs. Marine Biology 69 (3): 309-320.

Jones, M.B. \& M.J. Simons. 1983. Latitudinal variation in reproductive characteristics of a mud crab, Helice crassa (Grapsidae). Bulletin of Marine Science 33: 656-670.

Lasiak, T. \& A. McLachlan. 1987. Opportunistic utilization of mysid shoals by surf zone teleosts. Marine Ecology Progress Series 37: 1-7.

Loureiro-Fernandes, L. \& A.M.S. Gama. 1996. Molting cycle in Metamysidopsis munda (Crustacea: Mysidacea). Nauplius 4: 171-172.

Mauchline, J. 1965. Breeding and fecundity of Praunus inermis (Crustacea, Mysidacea Journal of the Marine Biological Association of the United Kingdom 45: 663-671. 
Mauchuine, J. 1971a. The biology of Schistomysis kervillei (Crustacea, Mysidacea). Journal of the Marine Biological Association of the United Kingdom 51: 653:658.

Mauchline, J. 1971b. The biology of Neomysis integer (Crustacea, Mysidacea). Journal of the Marine Biological Association of the United Kingdom 51: 347:354.

Mauchline, J. 1973. The broods of British Mysidacea (Crustacea). Journal of the Marine Biological Association of the United Kingdom 53: 801-817.

Mauchline, J. 1980. The biology of mysids and euphausiids. Advances in Marine Biology. New York, Academic Press, 681p.

Mauchline, J. 1985. Growth in mysids and euphausiids. In: A.M. WENNER (Ed.). Crustacean Issues 3 - Factors in adult growth. A.A. Balkema, Rotterdam, The Netherlands, CRC Press, 365p.

McKenney, C.L., 1994. Resistance patterns to salinity and temperature in an estuarine mysid (Mysidopsis bahia) in relation to its life cycle. Comparative Biochemistry and Physiology, Part A. Physiology, 109 (1): 199-208.

Modde, T. \& S.T. Ross. 1983. Trophic relationships of fishes occurring within a surf zone habitat in the northern Gulf of Mexico. Northeast Gulf Science 6 (2): 109-120.

Murano, M. 1999. Mysidacea, p. 1099-1140. In: D. Boltovskoy. (Ed). South Atlantic Zooplankton. Leiden, Backhuys Publishers, 705p.

Pezzack, D.S. \& S. Corey. 1979. The life history and distribution of Neomysis americana (Smith) (Crustacea, Mysidacea) in Passamaquoddy Bay. Canadian Journal of Zoology 57: 785793.

Richoux, N.B.; D. Debel \& R.J. Thompson. 2004. Population biology of hyperbenthic crustaceans in a cold water environment (Conception Bay, Newfoundland). I. Mysis mixta (Mysidacea). Marine Biology 144: 881-894.

Rörig, L.R.; C. Resgalla Jr; P.R. Pezzuto; E. dos S. Alves \& F. Morelli. 1997. Análise ecológica de um processo de acumulação da diatomácea Anaulus sp. na zona de arrebentação da praia de Navegantes (Santa Catarina, Brasil). Oecologia Brasiliensis
3: 29-43.

SAn Vicente, C. \& J.C. Sorbe 1993. Biologie du Mysidacé suprabenthique Schistomysis parkeri Norman, 1892 dans la zone sud du Golfe de Gascogne (Plage D'Hendaye). Crustaceana 65 (2): 222-252.

SHoRT, A.D. 1996. The role of wave height, period, slope, tide range and embaymentisation in beach classifications: a review. Revista Chilena de Historia Natural 69: 589-604.

Silva, V.M. 1970. Metamysidopsis macaensis, nova espécie de Crustacea Mysidacea. Atas da Sociedade de Biologia do Rio de Janeiro 13: 199-201.

SILVA, V.M. 1971. Bowmaniella (Bowmaniella) recifensis sp. nov. de Crustacea, Mysidacea. Atas da Sociedade de Biologia do Rio de Janeiro 14: 185-187.

SoARes, C.R.; C.A. Borzone \& J.R.B. SouzA. 1997. Variações morfológicas e sedimentológicas ao longo de um ciclo anual numa praia arenosa no sul do Brasil. Oecologia Brasiliensis 3: 245258.

Takahashi, K. \& K. KaWaguchi. 1995. Inter- and intraspecific zonation in three species of sand burrowing mysids, Archaeomysis kokuboi, A. japonica and Iiella ohshimai, in Otsuchi Bay, northeaster japan. Marine Ecology Progress Series 116: 75 84.

Webi, P.R. \& T.H. Wooldridge. 1987. Feeding of Mesopodopsis slabberi (Crustacea, Mysidacea) on naturally occurring phytoplankton. Marine Ecology Progress Series 38: 115-123.

Wooldridge, T.H. 1981. Zonation and distribution of the beach mysid, Gastrosaccus psammodytes (Crustacea: Mysidacea). Journal of Zoology 193: 183-189.

Wooldridge, T.H. 1983. Ecology of beach and surf-zone mysid shrimp in the eastern Cape, South Africa. In: A. McLachlan $\&$ T. Erasmus (Eds.). Sandy beaches as ecosystems. The Hague, W. Junk, 460p.

Wright, L.D. \& A.D. SHORT. 1984. Morphodynamic variability of surf zones and beaches: a synthesis. Marine Geology 56: 93-118.

Submitted: 28.VIII.2007; Accepted: 08.IX.2008.

Editorial responsibility: Georgina Bond-Buckup 